\title{
Development of Objective Ranking System for Tertiary Institutions in Developing Nations
}

\author{
Gabriel Atanbiyi', Benjamin Aribisala ${ }^{122}$, Oluwayemisi Nyaaku ${ }^{1}$ and Olusola Olabanjo'
}

\begin{abstract}
${ }^{1}$ Department of Computer Science, Faculty of Science, Lagos State University, Nigeria

${ }^{2}$ Department of Neuroimaging Sciences, Center for Clinical Brain Sciences, University of Edinburgh, Edinburgh UK
\end{abstract}

\section{Correspondence \\ Gabriel Atanbiyi \\ Department of Computer Science, \\ Faculty of Science, Lagos State University, Email:gabrielatanbiyi@gmail.com}

\section{Funding information}

Self-Sponsored

\begin{abstract}
:
Introduction: University ranking has become increasingly important in recent years because it creates a platform for competition amongst universities and also serves as a marketing tool in communicating performances of universities which could help them to build international reputation. Also, ranking could serve as a guide for prospective students seeking admission into tertiary institutions. There are many ranking systems used by developed nations but some of the parameters employed by these internationally accepted ranking systems are not easily available in the developing world. Additionally, some parameters that are important in developing are not included in the global rating. Hence, an objective ranking system that will capture the parameters relevant to the universities in developing nation is desirable.

Aim: Here, we propose an objective ranking system that will capture the peculiarities of the universities in developing nations.

Materials and Methods: Seventeen criteria relevant to developing nations were used to propose a new ranking system. Web crawling algorithm was used to extract the values of the criteria for each of the universities used as a case study. A total score based on the weight of criteria was calculated for each university and used for ranking. System implementation was carried out using PHP and Python.

Results: The best five universities from the proposed ranking system were University of Ibadan, Obafemi Awolowo University, University of Lagos, University of Benin and University of llorin.

Conclusion: The proposed ranking system will give an objective, better and more reliable ranking result for universities in developing nations than other existing ranking systems because it contains realistic and objective parameters available in developing nations.

Keywords: University Ranking, university, higher institutions, developing nations, Nigerian universities
\end{abstract}




\section{INTRODUCTION}

A University is the highest citadel of learning which has the primary goals of awarding degrees, conducting research and rendering community services. The existence of Universities can be traced to 859 AD when the first University in the world was founded, that is the University of Karueein in Fez [1]. Since then, most countries of the world have been establishing Universities and the number is still increasing. The importance of education and its strong and positive correlation with the global and national economy growth can explain the increase in number of universities witnessed in all nations of the world. Another factor that could contribute to the increase in the number of universities is the global increase in population. This increase in the number of universities has also introduced differences in the standard and quality of universities. Most nations of the world have both governmental and non-governmental agencies that ensure and moderate quality of educational sectors, of which university is one [2]. Albeit, there is a well-known competition amongst the universities in the world today especially in area of which one is better than the other. One approach to this competition is ranking, which makes it possible to compare many universities based on certain criteria [3-5]. The advent of computer and advancement of information technology have been major vehicles in the ranking of universities because many of the information needed for ranking are now available online.

Universities ranking has become increasingly important in recent years especially among universities dons because it creates a platform for competition among the universities and also serves as an advertising tool in publicizing their academic performance [5]. Ranking could also serve as a guide for prospective students and also helps a university to identify her area of weaknesses and make efforts towards solving them [6]. Ranking can help funders and stakeholders to identify where to put their funds towards improving university education, research and innovations [4].

LASU Journal of Research and Review in Science
The emergence of ranking systems can be traced back to 1865 when a study examined scholars and quality of higher institutions in Europe [7]. Since that time, there have been a lot of global efforts at classification and ranking of universities and colleges. One of the earliest of these was the effort of the Carnegie Foundation at classification of higher institutions using five criteria, namely, the award of doctorate degree, award of masters' degrees, award of bachelor degrees, associate colleges and special focus institutions [8]. The first well published ranking was the ranking of the Universities and colleges in the USA by the USA magazine called the US News and World Report in 1983 and their ranking was based on the classification by the Carnegie Foundation [8, 9]. Consequently, the ranking of universities today can therefore be traced to the pioneering efforts of the Carnegie Foundation. Another effort on university ranking that is worth mentioning is that of the British. In 1993, a London newspaper called the Financial Times published a league table which was used to rank tertiary institutions in the United Kingdom 'for the primary purpose of helping potential applicants that were seeking admission to study the right course and choose the appropriate institutions [9]. Since that time, there has been a proliferation of ranking systems, both at national and global levels [10].

Currently, there are many global ranking systems; some of the common ones are the Academic Ranking of World Universities (ARWU), Webometeric Ranking of World Universities (WRWU), Quacquarelli Symonds World University Ranking, formally known as Times Higher Education QS World University Ranking (QS), Leiden Ranking and Performance Ranking of Scientific Papers for Research Universities (HEEACT) [11-13].

University ranking systems differ based on criteria used, performance indicators and weights assigned to each criterion [14]. In 2006, at the International Ranking Expert Group's meeting, a guideline for university ranking known as the 'Berlin Principles' was developed to serve as a guide for researchers in 
ranking $[12,15]$. The guideline contains information on clarity of purpose, criteria weighting, data collection and result presentation.

Most of the global ranking systems were designed for developed nations and hence made an assumption that the information such as economic activities [10] and employers rating are easily available online or through an easy direct contact. Unfortunately, many universities in the developing countries are not visible online [16]. Even where some universities have websites, such websites do not have most of the information required by the global ranking systems [4]. Also, poor research funding, low income and poor facilities are some of the characteristics of the universities in the developing countries [17, 18]. Additionally, many universities in the developing nations do not have a good record keeping system or policy on data access. These problems make it very difficult to rank the universities in the developing nations using the criteria established for developed nations [4]. The aim of this research was hence, to develop an objective ranking system that will account for the peculiarities of developing nations.

\section{MATERIAL AND METHODS}

\subsection{SELECTION OF CRITERIA FOR UNIVERSITY RANKING}

We carried out a thorough literature search and identified 10 existing ranking systems $[7,11-13,19$, 20] namely;1.Academic Ranking of World Universities (ARWU), 2.The Webometric Ranking of World Universities (WRWU), 3.Quacquarelli Symonds World University Ranking, formally known as Times Higher Education QS World University Ranking (QS), 4.Performance Ranking of Scientific Papers for Research Universities (HEEACT), 5.Leiden(CWTS), 6.SCImago Institutional Rankings (SCIMAGO), 7.Global University Rankings (GUR), 8.Rating of Educational Resources, Russia(RATER), 9.World University Ranking (Times Higher Education/Thomson
Reuters (THE-TR) and 10.The National Universities Commission Ranking System (NUC). RATER and THE-TR used the same set of criteria and they were hence treated as identical and represented as THETR. Twenty-two distinct criteria were identified from these systems (Table 1) and grouped to identify the commonalities between the ranking systems (Table 2, Figure 1).

Table 2 shows that criteria 4 (number of publications) was the most commonly used criteria and used by eight ranking systems whereas 9 criteria $(1,13,14,15$, $16,19,20,21$ and 22) were the least used as they were used by only few ranking systems. All criteria used by at least two ranking systems were considered important and hence selected for inclusion in the current study. Criteria 8, 14, 16 and 20 were excluded because the information is not easily available in most Universities in the developing countries. Criteria 13 (Number of highly cited papers) were also not included because the information from it is already available from criteria 4 (Number of publications) and $12(\mathrm{H}$ index). Out of the ten existing systems, only the ranking from developing nation i.e. NUC used criteria 19 (Academic programmes with full accreditation status), 21 (student completion rate) and 22(Academic staff at professorial cadre). These three criteria were included in the proposed system because of the importance of accreditation, student completion ratio and the number of senior academic staff in the University. A total of 17 criteria were finally selected (see Table 1, those without asterisk).In summary, the criteria selected for the proposed system are number of Nobel prizes by Alumni, number of Nobel prizes by faculty, No of times faculty were cited, Number of Publications, Visibility of the university on the web, Size of the university website, Number of MultiDimensional Files, Faculty/Student ratio, International Faculty, International Students, H-Index, Patents, PhDs Awarded, University Popularity, Academic programmes with full accreditation status, Student completion rate and Academic staff of the university at professorial level. 
Table 1: Criteria used by the existing University Ranking Systems

\begin{tabular}{|l|l|l|l|}
\hline $\mathbf{S} / \mathbf{N}$ & Criteria & S/N & \multicolumn{1}{c|}{ Criteria } \\
\hline 1 & Nobel prize by Alumni & 12 & H-Index \\
\hline 2 & Nobel prize by faculty & $13^{*}$ & Number of highly cited papers \\
\hline 3 & Number of times faculty were cited & $14^{*}$ & International Collaborations \\
\hline 4 & Number of Publications & 15 & Patents \\
\hline 5 & Visibility of the university on the web & $16^{*}$ & Economic activity/Innovation \\
\hline 6 & Size of the university website & 17 & PhDs Awarded \\
\hline 7 & Number of Multi-Dimensional Files & 18 & University Popularity \\
\hline $8^{*}$ & Employer Review & 19 & Academic programmes with full accreditation status \\
\hline 9 & Faculty/Student ratio & $20^{*}$ & Stability of the university calendar \\
\hline 10 & International Faculty & 21 & Student completion rate \\
\hline 11 & International Students & 22 & Academic staff of the university at professorial level \\
\hline
\end{tabular}

*-Denotes the criteria not used in the proposed system in the current study

Table 2: Existing Ranking Systems and their Criteria

\begin{tabular}{|l|l|l|l|l|l|l|l|l|l|l|l|l|l|l|l|l|l|l|l|l|l|l|}
\hline $\begin{array}{l}\text { C Criteria } \\
\text { S/NO }\end{array}$ & $\mathbf{1}$ & $\mathbf{2}$ & $\mathbf{3}$ & $\mathbf{4}$ & $\mathbf{5}$ & $\mathbf{6}$ & $\mathbf{7}$ & $\mathbf{8}$ & $\mathbf{9}$ & $\mathbf{1 0}$ & $\mathbf{1 1}$ & $\mathbf{1 2}$ & $\mathbf{1 3}$ & $\mathbf{1 4}$ & $\mathbf{1 5}$ & $\mathbf{1 6}$ & $\mathbf{1 7}$ & $\mathbf{1 8}$ & $\mathbf{1 9}$ & $\mathbf{2 0}$ & $\mathbf{2 1}$ & $\mathbf{2 2}$ \\
\hline 1. ARWU & 1 & 1 & 1 & 1 & 0 & 0 & 0 & 0 & 0 & 0 & 0 & 0 & 0 & 0 & 0 & 0 & 0 & 0 & 0 & 0 & 0 & 0 \\
\hline 2. WRWU & 0 & 0 & 0 & 1 & 1 & 1 & 1 & 0 & 0 & 0 & 0 & 0 & 0 & 0 & 0 & 0 & 0 & 0 & 0 & 0 & 0 & 0 \\
\hline 3. QS & 0 & 0 & 0 & 1 & 0 & 0 & 0 & 1 & 1 & 1 & 1 & 0 & 0 & 0 & 0 & 0 & 0 & 0 & 0 & 0 & 0 & 0 \\
\hline 4. HEEACT & 0 & 0 & 1 & 1 & 0 & 0 & 0 & 0 & 0 & 0 & 0 & 1 & 1 & 0 & 0 & 0 & 0 & 0 & 0 & 0 & 0 & 0 \\
\hline 5. Leiden & 0 & 0 & 1 & 1 & 0 & 0 & 0 & 0 & 0 & 0 & 0 & 0 & 0 & 0 & 0 & 0 & 0 & 0 & 0 & 0 & 0 & 0 \\
\hline 6. SCIMAG & 0 & 0 & 0 & 1 & 1 & 1 & 1 & 0 & 0 & 0 & 0 & 0 & 0 & 1 & 1 & 0 & 0 & 0 & 0 & 0 & 0 & 0 \\
\hline 7. GUR & 0 & 1 & 1 & 1 & 0 & 1 & 0 & 0 & 1 & 1 & 1 & 1 & 0 & 0 & 0 & 0 & 0 & 1 & 0 & 0 & 0 & 0 \\
\hline 8. THE/TH \\
R
\end{tabular}

Note that 1represents that the criterion is used in the corresponding ranking system and 0 represents not used. 


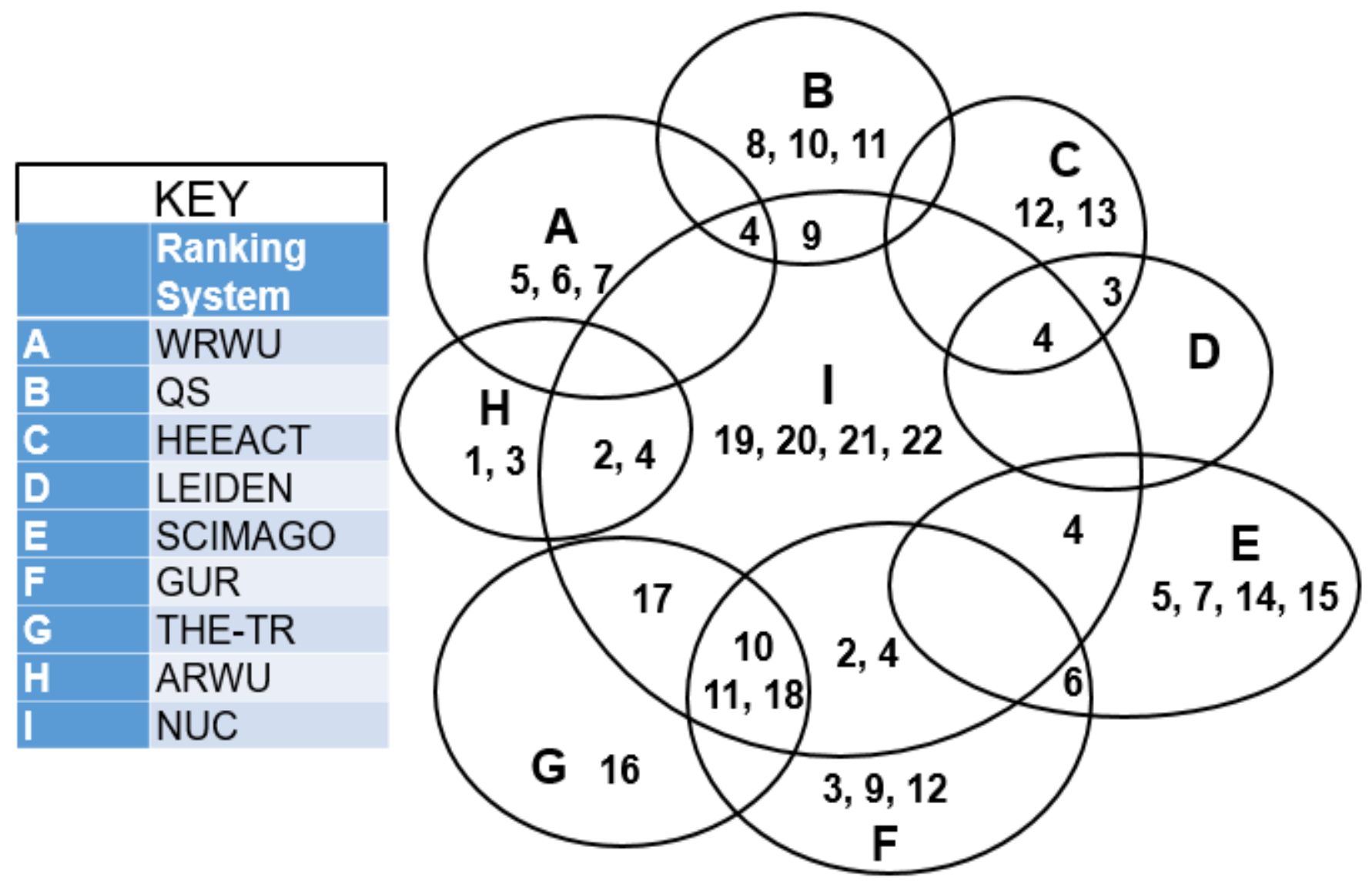

Figure 1: A Venn diagram showing the existing systems with their criteria

\subsection{Determination of Weights for the Criteria}

All the existing ranking systems do ranking by scoring each university based on some defined criteria and then attach weights to each of the criteria before summing up the scores. In view of this, a significant step in ranking is the determination of the weights to be assigned to each of the criteria. In this study, we empirically computed the weight of each criterion by using equation 1

$W=\frac{\sum x i}{N}$ Equation 1

Where $\mathrm{W}$ is the weight computed and used in this study, $x_{i}$ is the weight assigned by the existing systems for each criterion and $\mathrm{N}$ is the number of existing systems, $i$ is from 1 to $N$. Where no weight was given by the original ranking system, we assigned weights based on the importance of the criteria as it relates to the developing nations.

The final score for each university was computed using equation 2 and converted to \% using equation 3 . Then the $\%$ scores of all the universities were combined and ranked whereby the university with the highest score becomes the first and the university with the least score becomes the last in the rank.

$S=\sum W i Y i$ Equation 2 $F=\frac{\sum S i}{\sum S i k i} X 100 \% \ldots .$. Equation 3 
Where $S$ is the score for each university, $Y_{i}$ value of each criterion, $\mathrm{W}_{\mathrm{i}}$ is the weight of each criterion and $\mathrm{F}$ is the score $\mathrm{S}$ expressed in \%.

\subsection{SYSTEM IMPLEMENTATION}

The proposed ranking system was implemented for 166 universities out of 171 universities in Nigeria because 5 universities do not have online presence. The proposed ranking system was then implemented using PHP (web application) and Python (web crawling and parsing). The web crawler acts as an automated script which systematically traverses the internet pages. The crawler extracts relevant information from the web in a methodical and automated manner to support the well-crafted search engine queries. For each University website, a crawler flow was generated using sitemap. The crawler was configured to scrape the web regularly to keep the ranking up to date. Scheduling was carefully designed to reflect the possible time of update. This is crucial because some data items such as number of Professors and h-index are updated on a daily basis while others such as number of students admitted and number of graduates are usually changed on a yearly basis. Figure 2 shows the flow of the web-scraping technology used in the proposed ranking system.

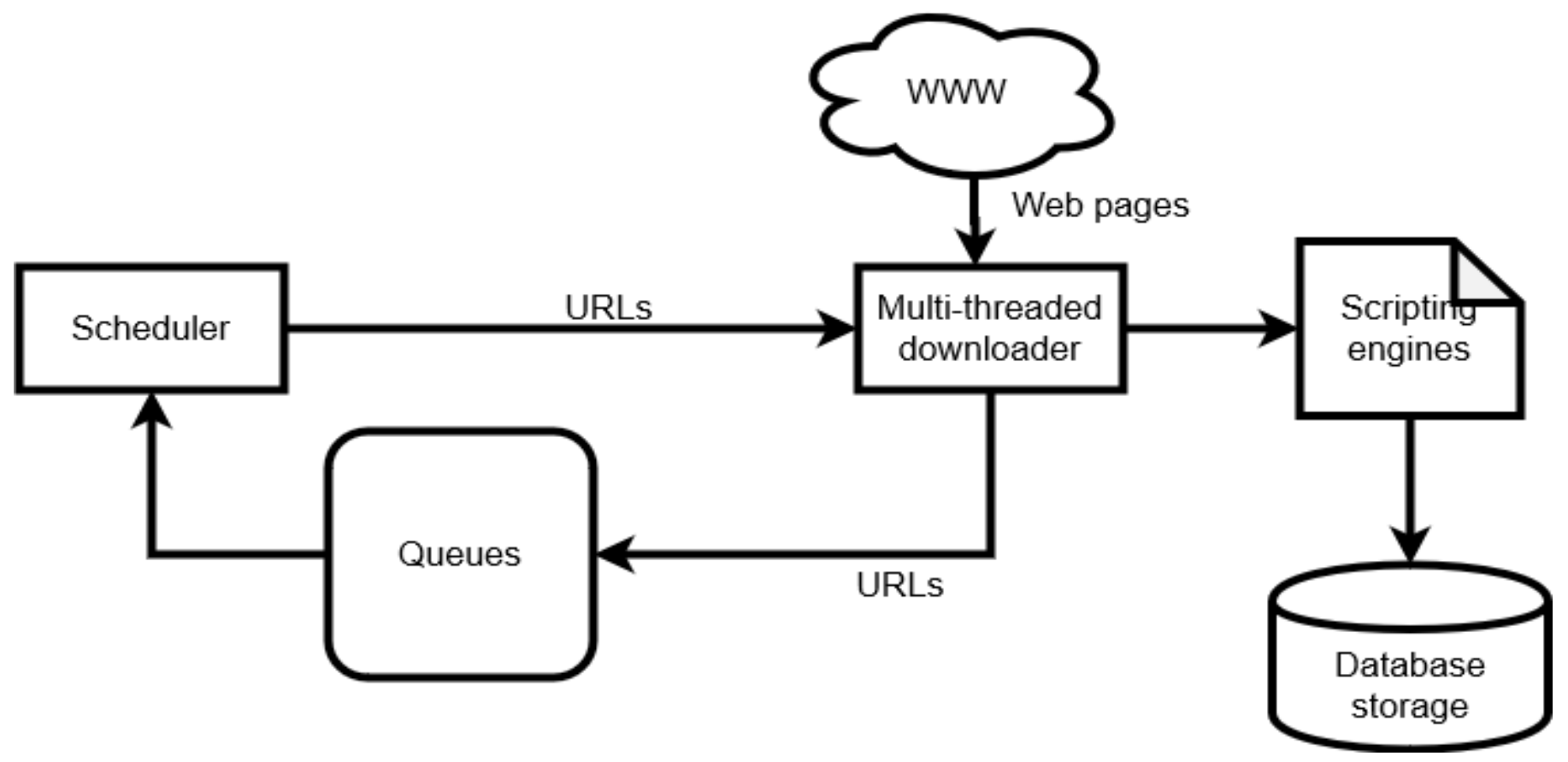

Figure 2: Workflow of developed University ranking web-scraping technology

The web crawler was used to extract the values of criteria that are available on the universities website (e.g. number of publication, visibility of the university on the web, size of the university website and number of multi-dimensional files). The other criteria that could not be automatically extracted by crawling due to unavailability of data or non-uniform web schema on the universities' websites were sourced from the National Universities Commission (NUC) official website (http://www.nuc.edu.ng) and inputted manually into the proposed ranking system. MSSQL was used for storing the data, a powerful server of minimum of 16GB RAM was used for a good crawling performance and a set of programming tools (JavaScript, Python and XPath libraries) were employed for scripting tasks.

\section{RESULTS AND DISCUSSION}

\subsection{RESULTS}


Table 1 show the 17 criteria used in developing the proposed ranking system while Table 3 shows the computed weight (\%) for each of the 17 criteria. Table 4 shows the result of the ranking as at $2^{\text {nd }}$ May 2020. Table 3 shows that criteria 2 (no of Nobel prizes by faculty), 3 (number of times faculty were cited), 4 (number of academic publication), 9 (faculty/student ratio), 12 (H-index), and 15 (patents) were assigned the highest weight of $10 \%$. These were followed by criteria 1 (no of nobel prizes by Alumni), 5 (university visibility), 6 (size of the university website) and 7 (number of multi-dimensional files) which were assigned 5\% while criteria 19 (academic programmes with full accreditation) and 22 (academic staff at professorial level) were assigned the least weight of $2 \%$. Note that criteria 19, 21 and 22 were not assigned any weight by the original ranking system that proposed them, but here we consider them very important and hence assigned them some weights as indicated.

Our results showed that the best 5 Universities in Nigeria are University of Ibadan, Obafemi Awolowo University, University of Lagos, University of Benin, University of llorin and the least 5 universities are Alex Ekwueme Federal University Ndufu Alike, Western Delta University, Caleb University, Clifford University and Bayelsa Medical University.

\subsection{DISCUSSION}

Here we propose an objective ranking system that combines the criteria used in the developed nations and those in the developing nations. The existing ranking systems are either focused on the developed nations e.g. Times New Higher [19] or has limited criteria like the NUC [13]. The proposed system used objectively and empirically selected criteria. The best University in Nigeria as reported by the proposed system is the University of Ibadan. This agrees with the general believe of most Nigerians because the University of Ibadan is the first University in Nigeria and it is well known to be a topmost University in Nigeria in the area of teaching and research outputs.
Our results show that Obafemi Awolowo University, University of Lagos, University of Benin and University of llorin are the $2^{\text {nd }}, 3^{\text {rd }}, 4^{\text {th }}$ and $5^{\text {th }}$ on the list. This also agrees with the believed of the general public on these universities. They are known for good service delivery and the dream of many prospective students. The least University according to the ranking of our system is Bayelsa Medical University. The University is very young and focuses on Medical science only. That could explain why the research output may be low and subsequently low ranking.

There are 2 ranking systems that ranked most of the Universities in Nigeria, these are the NUC [13] and the WRWU [7]. We could not compare our system with NUC because it has not released any ranking output for the past 19 years. In view of this, we only compared the ranking from our system with that of WRWU. Our system agrees very well with WRWU because the best 10 universities from our system has $70 \%$ agreement with the best 10 Universities from WRWU, 7 of the best from WRWU are within the best 10 in our system. Our system can be trusted better than WRWU because WRWU used only 4 criteria whereas our system used 17 criteria. Additionally, the criteria used by our system are very objective and can indicate the true ranking of universities in the developing nations.

The major strength of the proposed ranking system is the use of objective criteria which can easily be obtained from many Universities in developing countries either electronically or manually. The criteria used by most global ranking system are not easily obtainable in the developing countries but the criteria used by the proposed system are easily obtainable. Another strength is the objective computation of the weights assigned to the criteria used, whereas many ranking systems chose weights subjectively, we emperically calculated the weights used based. The proposed system is better than WRWU and NUC because we included some useful criteria not used by NUC and WRWU, for example number of Nobel prizes 
won by alumni, the number of times faculties were cited and patents. The major limitation of the proposed ranking system is that it was implemented for Nigerian Universities. Future work will consider including all Universities in the developing countries.

\section{CONCLUSION}

An objective ranking system dedicated for developing nations was proposed. The system is reliable and easy to implement. We implemented the proposed system for all Universities in Nigeria and the result of the ranking agrees with intuition and general believe of many Nigerians. We believe that the proposed ranking system will give a better and more reliable ranking result for universities in developing nations than other existing ranking systems because it contain realistic and objective parameters easily obtainable in developing nations.

\section{ACKNOWLEDGEMENTS}

We appreciate Mr. Adeyemi Mayowa, Mr. Mohammed Saba and Mr. Bamiro of the Department of Computer
Science for their help during data collection. We also appreciate the National Universities Commission (NUC) for their help in providing data for some criteria.

\section{COMPETING INTERESTS}

We declare that there are no competing interests that exist and this research do not received any grant or fund from either public or private organization.

\section{AUTHORS' CONTRIBUTIONS}

Atanbiyi Gabriel Babatunde conducted literature review, performed experiments and wrote the first draft of the paper. Benjamin Segun Aribisala conceived and designed the study, performed experiments, supervised the entire work and wrote the final draft of the paper. Oluwayemisi Nyaaku conducted literature review and contributed to the first draft. Olabanjo Olushola Aanu was involved in data collection, contributed to the first draft and was involved in software development. All authors read and approved the final draft of the manuscript. 
Table 3: Weight (\%) Assigned to the Criteria Selected for the Proposed Ranking System

\begin{tabular}{|c|c|c|c|}
\hline $\begin{array}{l}\text { Criteria } \\
\text { Number }\end{array}$ & $\begin{array}{l}\text { Number of Ranking } \\
\text { System using the } \\
\text { criteria }\end{array}$ & $\begin{array}{l}\text { Existing Weight used by various Ranking } \\
\text { System }\end{array}$ & $\begin{array}{l}\text { Assigned } \\
\text { Weight (\%) }\end{array}$ \\
\hline 4 & 8 & $20 \%, 12.5 \%, 20 \%, 10 \%,(\mathrm{)}, 13 \%, 6.7 \%,(\mathrm{l})$ & $10 \%$ \\
\hline 3 & 4 & $20 \%, 10 \%,(), 6.7 \%$ & $10 \%$ \\
\hline 2 & 4 & $20 \%, 6.7 \%,($ ) & $10 \%$ \\
\hline 9 & 3 & $20 \%, 20 \%,($ ) & $10 \%$ \\
\hline 12 & 2 & $20 \%, 20 \%$ & $10 \%$ \\
\hline 15 & 1 & $10 \%$ & $10 \%$ \\
\hline 6 & 3 & $25 \%, 5 \%, 5 \%$ & $5 \%$ \\
\hline 5 & 2 & $50 \%, 5 \%$ & $5 \%$ \\
\hline 7 & 2 & $12.5 \%, 10 \%$ & $5 \%$ \\
\hline 1 & 1 & $10 \%$ & $5 \%$ \\
\hline 22 & 1 & ( ) & $4 \%$ \\
\hline 10 & 4 & $5 \%, 5 \%, 3 \%,()$ & $3 \%$ \\
\hline 11 & 4 & $5 \%, 6.7 \%, 5 \%, 2 \%$ & $3 \%$ \\
\hline 18 & 3 & $5 \%, 4.5 \%,()$ & $3 \%$ \\
\hline 17 & 2 & $6 \%,()$ & $3 \%$ \\
\hline 19 & 1 & $($ ) & $2 \%$ \\
\hline \multirow[t]{2}{*}{21} & 1 & $($ ) & $2 \%$ \\
\hline & & TOTAL & $100 \%$ \\
\hline
\end{tabular}

Note that ( ) means no value of output weight was assigned. 
Table 4: Ranking of Nigerian Universities using the Proposed Ranking System

\begin{tabular}{|c|c|c|c|}
\hline $\mathbf{S} / \mathbf{N}$ & Name of Nigeria Universities & Score (\%) & Position \\
\hline 1 & University of Ibadan & $3.19 \times 10^{1}$ & $1^{\text {st }}$ \\
\hline 2 & Obafemi Awolowo University, Ile-Ife & $3.16 \times 10^{1}$ & $2^{\text {nd }}$ \\
\hline 3 & University of Lagos, Akoka & $1.86 \times 10^{1}$ & $3^{\text {rd }}$ \\
\hline 4 & University of Benin & $5.68 \times 10^{0}$ & $4^{\text {th }}$ \\
\hline 5 & University of Ilorin & $4.40 \times 10^{0}$ & $5^{\text {th }}$ \\
\hline 6 & Covenant University Ota & $2.82 \times 10^{0}$ & $6^{\text {th }}$ \\
\hline 7 & University of Nigeria, Nsukka & $1.44 \times 10^{0}$ & $7^{\text {th }}$ \\
\hline 8 & Ahmadu Bello University, Zaria & $3.85 \times 10^{-1}$ & $8^{\text {th }}$ \\
\hline 9 & AfeBabalola University, Ado-Ekiti - Ekiti State & $3.03 \times 10^{-1}$ & $9^{\text {th }}$ \\
\hline 10 & Usmanu Danfodiyo University, Sokoto & $2.97 \times 10^{-1}$ & $10^{\text {th }}$ \\
\hline 11 & Lagos State University, Ojo & $2.11 \times 10^{-1}$ & $11^{\text {th }}$ \\
\hline 12 & Bayero University, Kano & $1.99 \times 10^{-1}$ & $12^{\text {th }}$ \\
\hline 13 & Ladoke Akintola University of Technology & $1.89 \times 10^{-1}$ & $13^{\text {th }}$ \\
\hline 14 & NnamdiAzikiwe University, Awka & $1.24 \times 10^{-1}$ & $14^{\text {th }}$ \\
\hline 15 & Ekiti State University & $1.22 \times 10^{-1}$ & $15^{\text {th }}$ \\
\hline 16 & University of Calabar & $1.19 \times 10^{-1}$ & $16^{\text {th }}$ \\
\hline 17 & Tai Solarin University of Education, ljebu Ode & $1.01 \times 10^{-1}$ & $17^{\text {th }}$ \\
\hline 18 & Federal University of Agriculture, Abeokuta & $9.13 \times 10^{-2}$ & $18^{\text {th }}$ \\
\hline 19 & Federal University of Technology, Owerri & $8.80 \times 10^{-2}$ & $19^{\text {th }}$ \\
\hline 20 & Federal University, Lafia, Nasarawa State & $8.76 \times 10^{-2}$ & $20^{\text {th }}$ \\
\hline 21 & Augustine University & $8.76 \times 10^{-2}$ & $21^{\text {st }}$ \\
\hline 22 & SuleLamido University, Kafin Hausa, Jigawa & $8.34 \times 10^{-2}$ & $22^{\text {nd }}$ \\
\hline 23 & Summit University & $7.25 \times 10^{-2}$ & $23^{\text {rd }}$ \\
\hline 24 & Novena University, Ogume & $7.12 \times 10^{-2}$ & $24^{\text {th }}$ \\
\hline 25 & Ambrose Alli University, Ekpoma & $7.08 \times 10^{-2}$ & $25^{\text {th }}$ \\
\hline 26 & Bingham University, New Karu & $6.58 \times 10^{-2}$ & $26^{\text {th }}$ \\
\hline 27 & Enugu State University of Science and Technology & $6.10 \times 10^{-2}$ & $27^{\text {th }}$ \\
\hline 28 & Ondo State University of Medical Sciences & $5.32 \times 10^{-2}$ & $28^{\text {th }}$ \\
\hline 29 & Federal University of Technology, Akure & $5.23 \times 10^{-2}$ & $29^{\text {th }}$ \\
\hline 30 & Kola Daisi University Ibadan, Oyo State & $4.82 \times 10^{-2}$ & $30^{\text {th }}$ \\
\hline 31 & Kogi State University Anyigba & $4.78 \times 10^{-2}$ & $31^{\text {st }}$ \\
\hline 32 & Olabisi Onabanjo University, Ago Iwoye & $4.11 \times 10^{-2}$ & $32^{\text {nd }}$ \\
\hline 33 & Al-Qalam University, Katsina & $3.74 \times 10^{-2}$ & $33^{\text {rd }}$ \\
\hline 34 & Kwara State University, Ilorin & $3.65 \times 10^{-2}$ & $34^{\text {th }}$ \\
\hline 35 & University of Uyo, Uyo & $3.32 \times 10^{-2}$ & $35^{\text {th }}$ \\
\hline 36 & Federal University of Petroleum Resources, Effurun & $2.84 \times 10^{-2}$ & $36^{\text {th }}$ \\
\hline
\end{tabular}




\begin{tabular}{|c|c|c|c|}
\hline 37 & University of Africa Toru Orua, Bayelsa State & $2.69 \times 10^{-2}$ & $37^{\text {th }}$ \\
\hline 38 & Federal University, Oye-Ekiti, Ekiti State & $2.40 \times 10^{-2}$ & $38^{\text {th }}$ \\
\hline 39 & Umar Musa YarAdua University Katsina & $2.14 \times 10^{-2}$ & $39^{\text {th }}$ \\
\hline 40 & African University of Science \& Technology, Abuja & $2.07 \times 10^{-2}$ & $40^{\text {th }}$ \\
\hline 41 & PAMO University of Medical Sciences, Portharcourt & $2.06 \times 10^{-2}$ & $41^{\text {st }}$ \\
\hline 42 & Nasarawa State University Keffi & $2.01 \times 10^{-2}$ & $42^{\text {nd }}$ \\
\hline 43 & AdekunleAjasin University, Akungba & $1.97 \times 10^{-2}$ & $43^{\text {rd }}$ \\
\hline 44 & Southwestern University, Oku Owa & $1.96 \times 10^{-2}$ & $44^{\text {th }}$ \\
\hline 45 & Federal University, Dutsin-Ma, Katsina & $1.62 \times 10^{-2}$ & $45^{\text {th }}$ \\
\hline 46 & Tansian University, Umunya & $1.39 \times 10^{-2}$ & $46^{\text {th }}$ \\
\hline 47 & Ebonyi State University, Abakaliki & $1.32 \times 10^{-2}$ & $47^{\text {th }}$ \\
\hline 48 & Kano University of Science \& Technology, Wudil & $1.24 \times 10^{-2}$ & $48^{\text {th }}$ \\
\hline 49 & Mountain Top University & $1.19 \times 10^{-2}$ & $49^{\text {th }}$ \\
\hline 50 & Federal University, Gusau, Zamfara & $1.14 \times 10^{-2}$ & $50^{\text {th }}$ \\
\hline 51 & Air Force Institute of Technology, Kaduna & $1.13 \times 10^{-2}$ & $51^{\text {st }}$ \\
\hline 52 & Sokoto State University & $1.08 \times 10^{-2}$ & $52^{\text {nd }}$ \\
\hline 53 & Federal University of Technology, Minna & $1.06 \times 10^{-2}$ & $53^{\text {rd }}$ \\
\hline 54 & Bauchi State University, Gadau & $9.39 \times 10^{-3}$ & $54^{\text {th }}$ \\
\hline 55 & Edwin Clark University, Kaigbodo & $8.84 \times 10^{-3}$ & $55^{\text {th }}$ \\
\hline 56 & River State University & $7.92 \times 10^{-3}$ & $56^{\text {th }}$ \\
\hline 57 & Michael Okpara University of Agricultural, Umudike & $6.12 \times 10^{-3}$ & $57^{\text {th }}$ \\
\hline 58 & Kings University, Ode Omu & $6.08 \times 10^{-3}$ & $58^{\text {th }}$ \\
\hline 59 & Bells University of Technology, Otta & $5.99 \times 10^{-3}$ & $59^{\text {th }}$ \\
\hline 60 & Federal University, Kashere, Gombe State & $5.61 \times 10^{-3}$ & $60^{\text {th }}$ \\
\hline 61 & Federal University, Birnin-Kebbi & $5.15 \times 10^{-3}$ & $61^{\text {st }}$ \\
\hline 62 & Paul University, Awka - Anambra State & $5.11 \times 10^{-3}$ & $62^{\text {nd }}$ \\
\hline 63 & Hezekiah University, Umudi & $4.86 \times 10^{-3}$ & $63^{\text {rd }}$ \\
\hline 64 & Landmark University, Omu-Aran. & $4.65 \times 10^{-3}$ & $64^{\text {th }}$ \\
\hline 65 & Obong University, ObongNtak & $4.53 \times 10^{-3}$ & $65^{\text {th }}$ \\
\hline 66 & Ondo State University of Science and Technology Okitipu & $4.48 \times 10^{-3}$ & $66^{\text {th }}$ \\
\hline 67 & University of Port Harcourt, Port Harcourt & $4.19 \times 10^{-3}$ & $67^{\text {th }}$ \\
\hline 68 & Joseph Ayo Babalola University, Ikeji-Arakeji & $4.07 \times 10^{-3}$ & $68^{\text {th }}$ \\
\hline 69 & AbubakarTafawaBalewa University, Bauchi & $3.78 \times 10^{-3}$ & $69^{\text {th }}$ \\
\hline 70 & Lead City University, Ibadan & $3.78 \times 10^{-3}$ & $70^{\text {th }}$ \\
\hline 71 & Osun State University Osogbo & $3.71 \times 10^{-3}$ & $71^{\text {st }}$ \\
\hline 72 & Akwal-bom State University, Ikot Akpaden & $3.66 \times 10^{-3}$ & $72^{\text {nd }}$ \\
\hline 73 & Christopher University Mowe & $3.64 \times 10^{-3}$ & $73^{\text {rd }}$ \\
\hline 74 & Madonna University, Okija & $3.55 \times 10^{-3}$ & $74^{\text {th }}$ \\
\hline 75 & Legacy University, Okija, Anambra State & $3.50 \times 10^{-3}$ & $75^{\text {th }}$ \\
\hline 76 & Crescent University & $3.48 \times 10^{-3}$ & $76^{\text {th }}$ \\
\hline 77 & Abia State University, Uturu & $3.31 \times 10^{-3}$ & $77^{\text {th }}$ \\
\hline
\end{tabular}




\begin{tabular}{|c|c|c|c|}
\hline 78 & Nile University of Nigeria, Abuja & $3.23 \times 10^{-3}$ & $78^{\text {th }}$ \\
\hline 79 & Adeleke University, Ede & $3.16 \times 10^{-3}$ & $79^{\text {th }}$ \\
\hline 80 & Greenfield University, Kaduna & $2.95 \times 10^{-3}$ & $80^{\text {th }}$ \\
\hline 81 & Mcpherson University, Seriki Sotayo, Ajebo & $2.88 \times 10^{-3}$ & $81^{\text {st }}$ \\
\hline 82 & Evangel University, Akaeze & $2.79 \times 10^{-3}$ & $82^{\text {nd }}$ \\
\hline 83 & Imo State University, Owerri & $2.63 \times 10^{-3}$ & $83^{\text {rd }}$ \\
\hline 84 & Igbinedion University Okada & $2.49 \times 10^{-3}$ & $84^{\text {th }}$ \\
\hline 85 & Spiritan University, Nneochi, Abia State & $2.06 \times 10^{-3}$ & $85^{\text {th }}$ \\
\hline 86 & Federal University Gashua, Yobe & $2.06 \times 10^{-3}$ & $86^{\text {th }}$ \\
\hline 87 & Federal University, Dutse, Jigawa State & $1.97 \times 10^{-3}$ & $87^{\text {th }}$ \\
\hline 88 & Hallmark University, ljebi-Itele, Ogun & $1.95 \times 10^{-3}$ & $88^{\text {th }}$ \\
\hline 89 & Crown Hill University Eiyenkorin, Kwara State & $1.95 \times 10^{-3}$ & $89^{\text {th }}$ \\
\hline 90 & Dominican University Ibadan Oyo State & $1.84 \times 10^{-3}$ & $90^{\text {th }}$ \\
\hline 91 & Arthur Javis University, Akpoyubo, Cross river State & $1.79 \times 10^{-3}$ & $91^{\text {st }}$ \\
\hline 92 & Bornu State University, Maiduguri & $1.73 \times 10^{-3}$ & $92^{\text {nd }}$ \\
\hline 93 & American University of Nigeria, Yola & $1.42 \times 10^{-3}$ & $93^{\text {rd }}$ \\
\hline 94 & University of Agriculture, Makurdi & $1.40 \times 10^{-3}$ & $94^{\text {th }}$ \\
\hline 95 & Eastern Palm University Ogboko, Imo State & $1.36 \times 10^{-3}$ & $95^{\text {th }}$ \\
\hline 96 & Godfrey Okoye University, Ugwuomu-Nike - Enugu State & $1.33 \times 10^{-3}$ & $96^{\text {th }}$ \\
\hline 97 & AjayiCrowther University, Ibadan & $1.30 \times 10^{-3}$ & $97^{\text {th }}$ \\
\hline 98 & Samuel Adegboyega University, Ogwa. & $1.27 \times 10^{-3}$ & $98^{\text {th }}$ \\
\hline 99 & Baze University & $1.03 \times 10^{-3}$ & $99^{\text {th }}$ \\
\hline 100 & Ignatius Ajuru University of Education, Rumuolumeni & $1.01 \times 10^{-3}$ & $100^{\text {th }}$ \\
\hline 101 & Fountain Unveristy, Oshogbo & $9.26 \times 10^{-4}$ & $101^{\mathrm{st}}$ \\
\hline 102 & Chukwuemeka Odumegwu Ojukwu University, Uli & $9.18 \times 10^{-4}$ & $102^{\text {nd }}$ \\
\hline 103 & Oduduwa University, Ipetumodu - Osun State & $9.09 \times 10^{-4}$ & $103^{\text {rd }}$ \\
\hline 104 & Pan-Atlantic University, Lagos & $8.89 \times 10^{-4}$ & $104^{\text {th }}$ \\
\hline 105 & Benue State University, Makurdi & $8.72 \times 10^{-4}$ & $105^{\text {th }}$ \\
\hline 106 & Federal University, Otuoke, Bayelsa & $8.30 \times 10^{-4}$ & $106^{\text {th }}$ \\
\hline 107 & Ibrahim Badamasi Babangida University, Lapai & $8.21 \times 10^{-4}$ & $107^{\text {th }}$ \\
\hline 108 & Gregory University, Uturu & $8.00 \times 10^{-4}$ & $108^{\text {th }}$ \\
\hline 109 & University of Abuja, Gwagwalada & $7.68 \times 10^{-4}$ & $109^{\text {th }}$ \\
\hline 110 & Eko University of Medical and Health Sciences ljanikin & $7.42 \times 10^{-4}$ & $110^{\text {th }}$ \\
\hline 111 & Gombe State Univeristy, Gombe & $7.29 \times 10^{-4}$ & $111^{\mathrm{st}}$ \\
\hline 112 & Gombe State University of Science and Technology & $6.91 \times 10^{-4}$ & $112^{\text {th }}$ \\
\hline 113 & Plateau State University Bokkos & $6.62 \times 10^{-4}$ & $113^{\text {th }}$ \\
\hline 114 & Delta State University Abraka & $6.58 \times 10^{-4}$ & $114^{\text {th }}$ \\
\hline 115 & Redeemers University, Ede & $6.37 \times 10^{-4}$ & $115^{\text {th }}$ \\
\hline 116 & Chrisland University & $6.29 \times 10^{-4}$ & $116^{\text {th }}$ \\
\hline 117 & Anchor University, Ayobo Lagos State & $6.25 \times 10^{-4}$ & $117^{\text {th }}$ \\
\hline
\end{tabular}




\begin{tabular}{|c|c|c|c|}
\hline 118 & National Open University of Nigeria, Lagos & $5.79 \times 10^{-4}$ & $118^{\text {th }}$ \\
\hline 119 & Niger Delta University Yenagoa & $5.07 \times 10^{-4}$ & $119^{\text {th }}$ \\
\hline 120 & Babcock University,llishan-Remo & $4.92 \times 10^{-4}$ & $120^{\text {th }}$ \\
\hline 121 & Salem University, Lokoja & $4.82 \times 10^{-4}$ & $121^{\text {st }}$ \\
\hline 122 & Adamawa State University Mubi & $4.49 \times 10^{-4}$ & $122^{\text {nd }}$ \\
\hline 123 & Edo University lyamo & $4.48 \times 10^{-4}$ & $123^{\text {rd }}$ \\
\hline 124 & Al-Hikmah University, Ilorin & $3.69 \times 10^{-4}$ & $124^{\text {th }}$ \\
\hline 125 & Taraba State University, Jalingo & $3.27 \times 10^{-4}$ & $125^{\text {th }}$ \\
\hline 126 & Caritas University, Enugu & $3.23 \times 10^{-4}$ & $126^{\text {th }}$ \\
\hline 127 & Nigerian Defence Academy Kaduna & $2.89 \times 10^{-4}$ & $127^{\text {th }}$ \\
\hline 128 & Kaduna State University, Kaduna & $2.72 \times 10^{-4}$ & $128^{\text {th }}$ \\
\hline 129 & Achievers University, Owo & $2.60 \times 10^{-4}$ & $129^{\text {th }}$ \\
\hline 130 & Cross River State University of Technology, Calabar & $2.47 \times 10^{-4}$ & $130^{\text {th }}$ \\
\hline 131 & Precious Cornerstone University, Oyo & $2.43 \times 10^{-4}$ & $131^{\text {st }}$ \\
\hline 132 & Crawford University Igbesa & $2.43 \times 10^{-4}$ & $132^{\text {nd }}$ \\
\hline 133 & Modibbo Adama University of Technology, Yola & $2.43 \times 10^{-4}$ & $133^{\text {rd }}$ \\
\hline 134 & Oyo State Technical University Ibadan & $2.18 \times 10^{-4}$ & $134^{\text {th }}$ \\
\hline 135 & Federal University, Wukari, Taraba State & $1.80 \times 10^{-4}$ & $135^{\text {th }}$ \\
\hline 136 & Bowen University, Iwo & $1.72 \times 10^{-4}$ & $136^{\text {th }}$ \\
\hline 137 & Kebbi State University of Science and Technology, Aliero & $1.63 \times 10^{-4}$ & $137^{\text {th }}$ \\
\hline 138 & Benson Idahosa University, Benin City & $1.51 \times 10^{-4}$ & $138^{\text {th }}$ \\
\hline 139 & Federal University, Lokoja, Kogi State & $1.38 \times 10^{-4}$ & $139^{\text {th }}$ \\
\hline 140 & Renaissance University, Enugu & $1.26 \times 10^{-4}$ & $140^{\text {th }}$ \\
\hline 141 & Skyline University, Kano & $1.14 \times 10^{-4}$ & $141^{\text {st }}$ \\
\hline 142 & Ritman University, IkotEkpene, Akwalbom & $7.92 \times 10^{-5}$ & $142^{\text {nd }}$ \\
\hline 143 & Nigerian Maritime University Okerenkoko, Delta State & $6.40 \times 10^{-5}$ & $143^{\text {rd }}$ \\
\hline 144 & Rhema University, Obeama-Asa - Rivers State & $4.53 \times 10^{-5}$ & $144^{\text {th }}$ \\
\hline 145 & Micheal \& Cecilia Ibru University & $4.23 \times 10^{-5}$ & $145^{\text {th }}$ \\
\hline 146 & Trinity University Ogun State & $4.14 \times 10^{-5}$ & $146^{\text {th }}$ \\
\hline 147 & Elizade University, Ilara-Mokin & $4.12 \times 10^{-5}$ & $147^{\text {th }}$ \\
\hline 148 & Moshood Abiola University of Science and Technology & $3.36 \times 10^{-5}$ & $148^{\text {th }}$ \\
\hline 149 & Kwararafa University, Wukari & $3.35 \times 10^{-5}$ & $149^{\text {th }}$ \\
\hline 150 & Nigerian Army University Biu & $2.52 \times 10^{-5}$ & $150^{\text {th }}$ \\
\hline 151 & Nigeria Police Academy Wudil & $1.65 \times 10^{-5}$ & $151^{\text {st }}$ \\
\hline 152 & Yobe State University, Damaturu & $9.66 \times 10^{-6}$ & $152^{\text {nd }}$ \\
\hline 153 & University of Medical Sciences, Ondo City & $7.81 \times 10^{-6}$ & $153^{\text {rd }}$ \\
\hline 154 & Coal City University Enugu State & $5.75 \times 10^{-6}$ & $154^{\text {th }}$ \\
\hline 155 & University of Jos, Jos & $4.50 \times 10^{-6}$ & $155^{\text {th }}$ \\
\hline 156 & Yusuf Maitama Sule University, Kano & $4.47 \times 10^{-6}$ & $156^{\text {th }}$ \\
\hline 157 & University of Maiduguri & $3.62 \times 10^{-6}$ & $157^{\text {th }}$ \\
\hline
\end{tabular}




\begin{tabular}{|c|l|l|l|}
\hline 158 & Veritas University & $1.31 \times 10^{-6}$ & $158^{\text {th }}$ \\
\hline 159 & Wesley University, Ondo & $1.23 \times 10^{-6}$ & $159^{\text {th }}$ \\
\hline 160 & Wellspring University, Evbuobanosa & $8.41 \times 10^{-7}$ & $160^{\text {th }}$ \\
\hline 161 & University of Mkar, Mkar & $5.82 \times 10^{-7}$ & $161^{\text {st }}$ \\
\hline 162 & Alex Ekwueme Federal University Ndufu Alike & $5.02 \times 10^{-7}$ & $162^{\text {nd }}$ \\
\hline 163 & Western Delta University, Ogahara, Delta State & $4.71 \times 10^{-7}$ & $163^{\text {rd }}$ \\
\hline 164 & Caleb University, Lagos & $2.29 \times 10^{-8}$ & $164^{\text {th }}$ \\
\hline 165 & Clifford University OwerrintaAbia State & $1.90 \times 10^{-8}$ & $165^{\text {th }}$ \\
\hline 166 & Bayelsa Medical University & $1.66 \times 10^{-8}$ & $166^{\text {th }}$ \\
\hline
\end{tabular}

\section{REFERENCES}

[1] Limited, G.W.R. Oldest higher-learning institution, oldest university. 2020; Available

from:https://www.guinnessworldrecords.c om/world-records/oldestuniversity?fb_comment_id $=88470352154$ 9256923508941002047.

[2] Büşra Almaa , E.C., Ezgi Övendirelic, University ranking systems and proposal of a theoretical framework for ranking of Turkish Universities: A case of management departments, in 12th International Strategic Management Conference, ISMC 2016. 2016, ScienceDirect: $28-30$ October 2016, Antalya, Turkey. p. $128-138$.

[3] Teodoro Luque-Martínez, N.F., Metaranking to position world universities. Studies in Higher Education, 2019.

[4] Sayed, O.H., Critical Treatise on University Ranking Systems. Open Journal of Social Sciences, 2019. 7: p. 39-51.

[5] Tim Pitman, D.E., Liang-Cheng Zhang, Paul Koshy, Julie McMillan, Constructing a ranking of higher education institutions based on equity: is it possible or desirable? Higher Education 2020.

[6] Marlo M. Vernon, E.A.B., Shaher Momani, Are university rankings useful to improve research? A systematic review. 2018.

[7] Dorothy Flora Khamala, E.O.M., Dorothy Muthoni Njiraine, Webometrics Ranking and Its Relationship to Quality Education and Research in Academic Institutions in Kenya. Library Philosophy and Practice (e-journal), 2018.
[8] McCormick, A.C., Classifying Higher Education Institutions: Lessons from the Carnegie Classification. Center for Postsecondary Research, Indiana University Bloomington, USA, 2013. 50(1): p. 65-75.

[9] Obasi, I.N., World University Rankings in a Market-driven Knowledge Society: Implications for African Universities. University of Botswana, Botswana, 2006.

[10] Emmanuel Mogaji, R.K., Felix Maringe, Watiri Kanyutu, University League Tables and Ranking Systems in Africa: Emerging Prospects, Challenges and Opportunities. 2020.

[11] Gualberto Buela-Casa, O.G.-M., Maria Paz Bermudez-Sanchez, Oscar VadilloMunozb, Comparative study of international academic rankings of universities. Akadémiai Kiadó, Budapest Scientometrics and Springer, Dordrecht, 2006(0138-9130).

[12] Rauhvargers, A., Global University Rankings and Their Impact. 2011.

[13] Peter Okebukola. Nigerian Universities and World Ranking: Issues, Strategies and Forward Planning. in AVCNU Conference 2011. Covenant University, Ota, June 2730, 2011

[14] Edwin Montes-Orozco, R.A.M.-G., Bibiana Obregon, Miguel Ángel GutiérrezAndrade, Mexican University Ranking Based on Maximal Clique. Educational Networking, 2020.

[15] Kevin Downing, P.J.L., Hiu Tin Leung, The history and development of higher education ranking systems. QS Asia News Network, 2018. 
[16] Alrence Santiago Halibas, L.B.R., Indu Govinda Pillai. Erbeth Gerald Delvo, Anju Matthew Cherian, Genevive Halasan Sumondong, Ozamiz City, Web Ranking of Higher Education Institutions: An SEO Analysis. 2020.

[17] Omoverere Agarin, W.E.N., Links and Web Impact Analyses of Nigerian Universities, in International Conference on Bridging the Digital Divide in Scholarly Communication in the South: Threats and Opportunities. 2006, Africa Regional Centre for Information Science University of Ibadan, Nigeria.: Centre for African Studies, University of Leiden, The
Netherlands during September 6 to September 8, 2006

[18] Rena, R., Emerging trends of higher education in developing countries. 2010.

[19] Rankings, T.T.H.E.W.U. World University Rankings. 2020; Available from: https://www.timeshighereducation.com/wo rld-university-rankings/2020/worldranking\#!/page/0/length/25/sort_by/rank/s ort_order/asc/cols/stats

[20] Isidro F. Aguillo, J.L.O., Webometric Ranking of World Universities: Introduction, Methodology, and Future Developments. Higher Education in Europe, 2008. 33(2): p. $233-244$. 